\title{
CHARACTERISTICS OF A Mg-PALYGORSKITE IN MIOCENE ROCKS, MADRID BASIN (SPAIN)
}

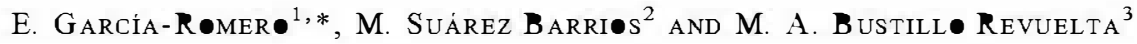 \\ ${ }^{1}$ Departamento de Cristalografía y Mineralogía, Facultad de C. C. Geológicas, Universidad Complutense, Madrid, Spain \\ ${ }^{2}$ Departamento de Geología, Universidad de Salamanca, Plaza de la Merced s/n 37008, Salamanca, Spain \\ ${ }^{3}$ Departamento de Geología, Museo Nacional de Ciencias Naturales, CSIC, José Gutiérrez Abascal 2, Madrid, Spain
}

\begin{abstract}
Palygorskite in Miocene mudstones, palustrine limestones and calcretes from the Esquivias locality (Madrid Basin, Spain) has been analyzed by X-ray diffraction, infrared spectroscopy, scanning electron microscopy, transmission electron microscopy and analytical electron microscopy to determine its characteristics and chemical composition. Other palygorskites from the literature are used as references. The mean structural formula obtained from the analysis of isolated particles is $\left(\mathrm{Si}_{7.87} \mathrm{Al}_{0.13}\right) \bullet_{2 \cdot}\left(\mathrm{Al}_{1.04} \mathrm{Fe}_{0.20}^{3+} \mathrm{Mg}_{3.11} \square \cdot 65\right)(\bullet \mathrm{H})_{2}\left(\bullet_{2}\right)_{4}\left(\mathrm{Ca}_{\mathbf{0} .2} \mathrm{~K}_{\mathbf{0}}{ }_{5} \mathrm{Na}_{\bullet .08}\right)$. This palygorskite has the largest $\mathrm{Mg}$ content reported in the literature, and it seems that, chemically, it fills the "compositional gap' existing between sepiolite and palygorskite. Infrared spectroscopy reveals the absence of trioctahedral $\mathrm{Mg}$ and therefore the possibility of the existence of magnesic clusters in the ribbons is discounted. An homogeneous distribution of the octahedral cations $\left(\mathrm{Al}, \mathrm{Fe}^{3+}\right.$ and $\mathrm{Mg}$ ) along the ribbons is proposed.

Key Words-Esquivias, FTIR Spectroscopy, Mg-palygorskite, Octahedral Occupancy, Palygorskite, Spain, Tajo Basin.
\end{abstract}

\section{INTRODUCTION}

Palygerskite is a fibrous clay mineral, the structure $\bullet$ which consists of ribbøns of a 2:1 phyllesilicate structure, linked by periodical inversion of the apical -xygens of the continueus tetrahedral sheet and thus the -ctahedral sheet is discontinuous. Bradley (1940) proposed the first structural pattern for palygørskite and suggested that the mineral has the formula $\mathrm{Si}_{8} \mathrm{Mg}_{5} \bullet_{2} \mathrm{O}(\mathrm{H})_{2}\left(\mathrm{H}_{2}\right)_{4} \cdot 4 \mathrm{H}_{2} \bullet$. When Al is incorperated inte the structure, it can fill any of the five ectahedral positions leaving vacancies.

The structural medel prepesed by Bradley has been followed by others. Drits and Alexandrova (1966) published a revision of chemical analyses of palygors-

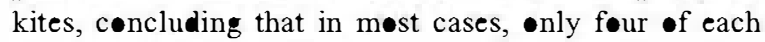
five octahedral positions can be eccupied. Therefore they suggested a diectahedral medel, as •pposed to the trioctahedral $\bullet$ ne postulated by Bradley. Later, Drits and

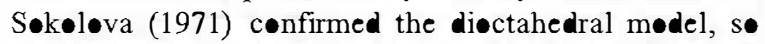
that in the ectahedral sheet, a position (the middle one) would be empty. This model has alse been propesed by Mifsud et al. (1978) based on chemical and thermal analysis $\bullet$ samples from different localities. Acc $\bullet$ ring to Serna et al. (1977) the number $\bullet$ ectahedral pøsitions per unit-cell in palygerskite is five, althøugh it does not seem possible that all can be filled. In most palygorskites, $\bullet$ nly four of each five pøsitions are filled, whereas søme seem to be completely diectahedral palygørskites.

\footnotetext{
* E-mail address of corresponding author: mromero@geo.ucm.es
}

Thus, the structural formula is $\mathrm{Si}_{8}\left(\mathrm{Mg}_{2} \mathrm{Al}_{2}\right) \boldsymbol{Q}_{20}$ $(\bullet)_{2}\left(\bullet \mathrm{H}_{2}\right)_{4} \cdot 4 \mathrm{H}_{2} \bullet$

Althøug palygerskite is relatively rare, it •ccurs in a great variety $\bullet$ envirønents. It is an authigenic mineral

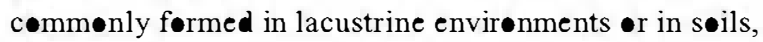
and it occasiønally appears in marine envirønments $\bullet$ assøciated with hydrothermal activity. Its •ccurrence is als frequently reported from calcretes, caliches or carbønate-rich søils (Verrecchia and Le Coustumer, 1996). The general cønditions of palygerskite stability have been discussed by Singer and Norrish (1974), Weaver and Beck (1977) and Jønes and Galán (1991).

Numerous authers have mentioned the presence of palygorskite in Spanish Tertiary basins. Torres-Ruiz et al. (1994) made a revision of the geochemistry of sepielite-palygerskite Spanish Neøgene depesits. The

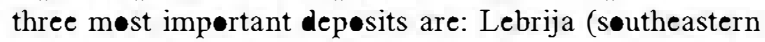
Spain), studied by Gønzález and Galán (1984) and Galán and Ferrer $(1982)$, and mined •ver hundreds of years for its use as a clarifying agent in wines; Torrejón (Cáceres), reported by Galán and Castille (1984); and Bercimuel (Segøvia) studied by Suárez et al. (1994 and 1995). The last is the only $\bullet$ ne still active. Few crystalløchemical data have been reported for these -ccurrences.

The presence of palygerskite in Esquivias has been

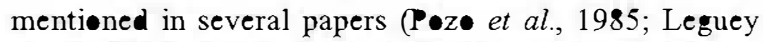

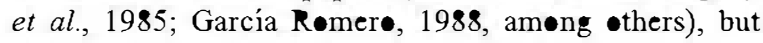

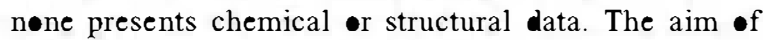
this work is to crystallechemically characterize the Esquivias palygorskite, which, in comparisøn to all -ther published data, has an anımaleus chemical compesition. 
These Mg-clay deposits are widely distributed within lacustrine and distal alluvial fan deposits from the Intermediate Unit (Miocene) of the Madrid Basin. To the northeast of Esquivias (Figure 1), thin $(30 \mathrm{~cm}$ thick) argillaceous beds are interlayered with calcretes/palustrine limestones. The palygorskite studied occurs in all these rocks mixed with calcite and other minerals, mainly sepiolite and opal (Bellanca et al., 1992; Bustillo and Garcia Romero, 2003). In the thin argillaceous beds, palygorskite coexists with sepiolite and smectites, but at the top it occurs alone and it is possible to obtain good samples. Palygorskite formed by direct precipitation from interstitial waters present in the calcretes/palustrine limestones. Part of the palygorskite included in these rocks formed later than calcite, and its formation may have been favored by the dissolution of calcite. There were very large amounts of $\mathrm{Mg}$ and Si available in the Madrid Basin, as indicated by the important deposits of $\mathrm{Mg}$-bentonite and sepiolite, and the presence of important silicifications.

\section{MATERIALS AND METHODS}

Apart from the samples from Esquivias, we also analyzed palygorskites from Attapulgus (Georgia, USA), Bercimuel (Segovia, Spain) and Torrejón el Rubio (Cáceres, Spain), in order to make a comparative study, and to use them as references. These palygorskites have been studied widely and reported in the literature.
Mineralogical characterization was performed by X-ray diffraction (XRD) using a Siemens D-500 XRD diffractometer with $\mathrm{CuK} \alpha$ radiation and a graphite monochromator. The samples used were random powder specimens scanned from 2 to $65^{\bullet} 20$ at $\mathbf{0 . 0 2} 20 / 3 \mathrm{~s}$ scan speed.

Particle morphology and textural relationships were established using scanning electron microscopy (SEM) and ransmission electron microscopy (TEM). The SEM observations were performed using a JE $\bigcirc$ JSM 6400 microscope, operating at $20 \mathrm{kV}$ and equipped with a Link System energy dispersive $\mathrm{X}$-ray (EDX) microanalyser. Prior to SEM examination, freshly fractured surfaces of representative samples were air dried and coated with $\mathrm{Au}$ under vacuum in an Ar atmosphere. The TEM observations were performed by depositing a drop of diluted suspension on a microscopic grid with collodion and coated with $\mathrm{Au}$.

The chemical composition was obtained using analytical electron microscopy (AEM) with TEM, in samples of great purity, using a JEOL 2000 FX microscope equipped with a double-tilt sample holder (up to a maximum of $\pm 45^{\circ}$ ) at an acceleration voltage of $200 \mathrm{kV}$, with $0.5 \mathrm{~mm}$ zeta-axis displacement and $0.31 \mathrm{~nm}$ point-to-point resolution. The microscope incorporates an OXF RD ISIS EDX spectrometer $(136 \mathrm{eV}$ resolution at $5.39 \mathrm{keV})$ and has its own software for quantitative analysis.

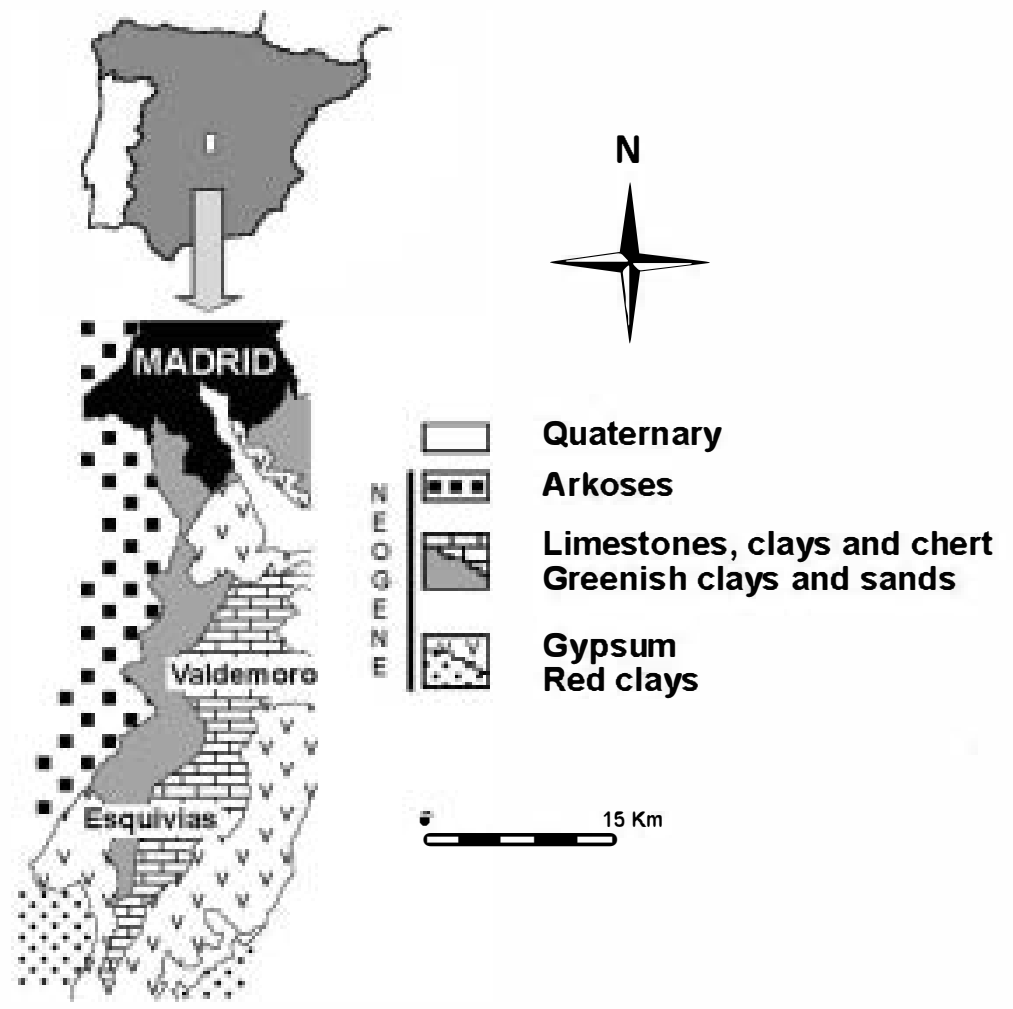

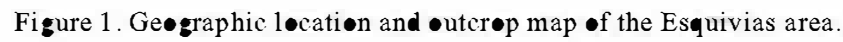


The structural formulae for palygorskite were calculated on the basis of 21 exygens per unit-cell. All the Fe present was considered as $\mathrm{Fe}^{3+}$ (owing to the limitation -f the technique), but the possible existence of $\mathrm{Fe}^{2+}$ should be taken inte account.

The FTIR spectra were recorded in the 4000 to $500 \mathrm{~cm}{ }^{1}$ ranges on a BRUKER EQUINOX 55 spectrmeter. The samples were prepared using the $\mathrm{KBr}$ pellet technique.

\section{RESULTS}

The samples studied contain palygorskite, calcite and quartz. Some samples are composed almost exclusively - $f$ palyzorskite, whereas others have considerable amounts of calcite (up to $30 \%$ ). Quartz is $\langle 5 \%$ in all samples and no ether phyllesilicates were identified. Figure 2 shows a representative diffraction pattern of Esquivias palygorskite.

Scanning electron micrographs of fracture surfaces reveal the characteristic fibrous morphology of the palygorskite (Figure 3a). The aggregates grow as dense fiber masses connected to each other in pure palyzorskite beds, or enmesh the calcite crystals and sprout out from their surfaces, cover them, and fill totally or partially the voids between carbenates. The fibers have an average length of $12 \mu \mathrm{m}$, and their diameters may vary between 0.15 and $0.5 \mu \mathrm{m}$ (Figure 3b).

The TEM images of ispersed Esquivias palygorskite show mainly: (1) azgregates of fibers grouped parallel to their $c$ axis, giving rise to particles of greater size; and (2) fibers growing ever crystals of calcite. Detailed -bservations of individual fibers allow us to see that

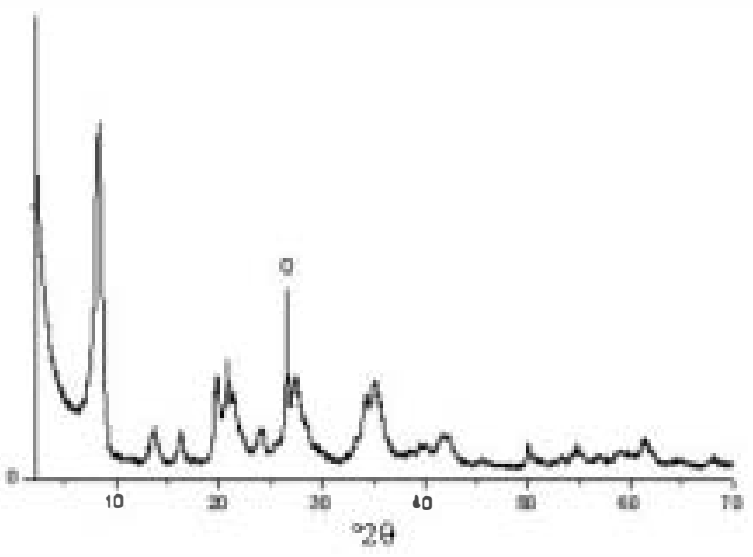

Figure 2. Randem powder XR patierns of the Esquivias palygeskite. - quark. All peaks •ther than that for quartz beleng t• palygerskite.

smaller units form each one of them. In the same way, the smaller units are arranged parallel. Amorphous phases have not been detected.

Table 1 shews structural formulae calculated from AEM of is lated clay particles of Esquivias samples and Table 2 those correspending to Attapulgus, Bercimuel and Torrejón. The mean structural formula botained for Esquivias palygorskite was $\left(\mathrm{Si}_{7}, \mathrm{Al}_{\bullet},{ }_{13}\right) \boldsymbol{\bullet}_{2}\left(\mathrm{Al}_{1.4}\right.$ $\left.\mathrm{Fe}_{\bullet 2}^{3+} \mathrm{Mg}_{3} 11 \square \bullet 65\right)\left(\bullet \mathrm{H}_{2}\right)_{2}\left(\mathrm{H}_{2}\right)_{4}\left(\mathrm{Ca} \bullet \bullet_{2} \mathrm{~K}_{\bullet} \bullet_{5} \mathrm{Na} \bullet \bullet 8\right)$. Esquivias samples are the richest in octahedral $\mathrm{Mg}$. The values of $\mathrm{Mg}$ atoms per half unit-cell range from 2.73 to 3.86 , with a mean value of 3.11 , whereas, as is shown, the total number of atoms of $\mathrm{Mg}$ from the reference samples studied does not exceed 2.47 atoms per half unit-cell (Attapulgus (2.06 2.47), Bercimuel
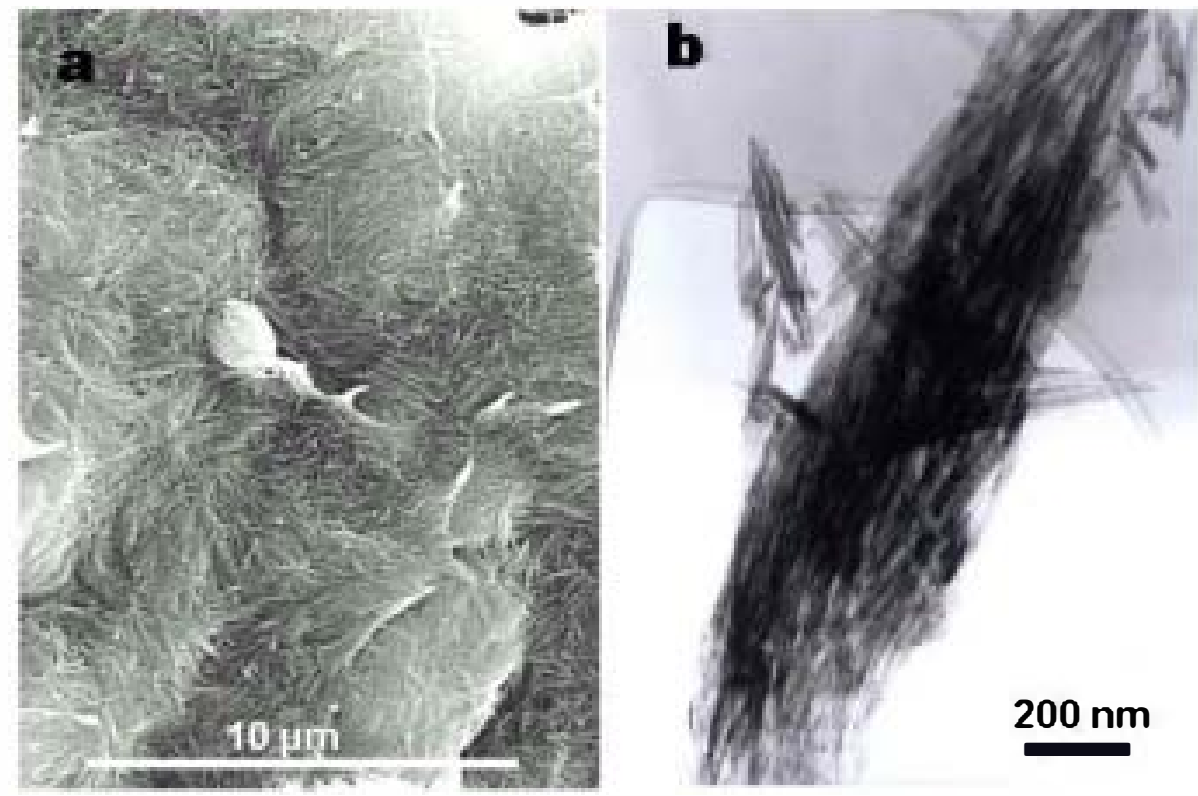

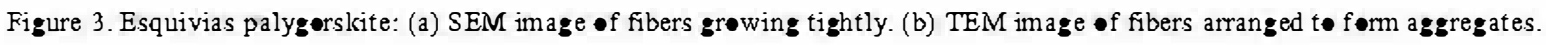


Table 1. Structural formulae from the Esquivias palygorskite samples, calculated from EDS analyses of isolated palygorskite particles. The number of cations is on the basis of $\boldsymbol{\theta}_{20}\left(\mathrm{OH}_{2}\left(\mathrm{H}_{2}\right)_{2}\right.$.

\begin{tabular}{|c|c|c|c|c|c|c|c|c|c|c|c|}
\hline & $\mathrm{Si}$ & ${ }^{\mathrm{rv}} \mathrm{Al}$ & $\Sigma \mathrm{t}$ & ${ }^{v} \mathrm{Al}$ & $\mathrm{Fe}^{3+}$ & $\mathrm{Mg}$ & $\mathrm{Ti}$ & $\Sigma o$ & $\mathrm{Ca}$ & $\mathrm{K}$ & $\mathrm{Na}$ \\
\hline 1 & 7.97 & 0.03 & 8.00 & 1.03 & 0.14 & 3.26 & & 4.43 & & 0.01 & 0.02 \\
\hline 2 & 7.93 & 0.07 & 8.00 & 1.07 & 0.19 & 3.15 & & 4.41 & & & \\
\hline 3 & 7.71 & 0.29 & 8.00 & 1.29 & 0.26 & 2.73 & & 4.28 & 0.04 & 0.10 & \\
\hline 4 & 7.98 & 0.02 & 8.00 & 1.07 & 0.22 & 3.08 & & 4.37 & & & \\
\hline 5 & 7.98 & 0.02 & 8.00 & 1.07 & 0.15 & 3.18 & & 4.40 & & & \\
\hline 6 & 7.92 & 0.08 & 8.00 & 1.04 & 0.17 & 3.23 & & 4.44 & & & \\
\hline 8 & 7.93 & 0.07 & 8.00 & 0.96 & 0.17 & 3.30 & & 4.43 & 0.02 & 0.03 & \\
\hline 9 & 7.89 & 0.11 & 8.00 & $\bullet .73$ & 0.06 & 3.86 & & 4.65 & & & \\
\hline 10 & 7.97 & 0.03 & 8.00 & 0.94 & 0.20 & 3.16 & & 4.30 & 0.13 & 0.04 & \\
\hline 21 & 7.85 & 0.15 & 8.00 & 1.05 & 0.10 & 3.32 & & 4.47 & 0.01 & 0.04 & \\
\hline 22 & 7.77 & 0.23 & 8.00 & 0.98 & 0.21 & 3.07 & 0.03 & 4.29 & 0.02 & 0.06 & 0.32 \\
\hline 23 & 7.78 & 0.22 & 8.00 & 1.09 & 0.21 & 2.98 & 0.02 & 4.30 & 0.02 & 0.06 & 0.21 \\
\hline 24 & 7.75 & 0.25 & 8.00 & 1.04 & 0.24 & 3.04 & 0.02 & 4.34 & 0.04 & 0.12 & 0.08 \\
\hline 25 & 7.79 & 0.21 & 8.00 & 1.11 & 0.32 & 2.73 & 0.02 & 4.18 & 0.04 & 0.12 & 0.19 \\
\hline 26 & 7.90 & 0.10 & 8.00 & 1.06 & 0.19 & 3.07 & & 4.32 & 0.02 & 0.05 & 0.13 \\
\hline 27 & 7.90 & 0.10 & 8.00 & 1.15 & 0.21 & 2.90 & & 4.26 & 0.05 & 0.08 & 0.02 \\
\hline 28 & 7.80 & 0.20 & 8.00 & 1.06 & 0.28 & 2.92 & 0.04 & 4.30 & 0.02 & 0.06 & 0.09 \\
\hline 29 & 7.92 & 0.08 & 8.00 & 0.92 & 0.20 & 3.28 & & 4.40 & 0.01 & 0.07 & 0.08 \\
\hline 30 & 7.69 & 0.31 & 8.00 & 0.98 & 0.20 & 3.27 & & 4.45 & 0.01 & 0.05 & 0.20 \\
\hline 31 & 7.88 & 0.12 & 8.00 & 1.20 & •. 26 & 2.73 & & 4.19 & 0.02 & 0.08 & $\bullet .16$ \\
\hline Mean & 7.87 & $\bullet .13$ & 8.00 & 1.04 & 0.20 & 3.11 & 0.01 & 4.36 & 0.02 & 0.05 & 0.08 \\
\hline
\end{tabular}

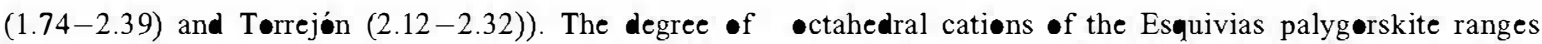

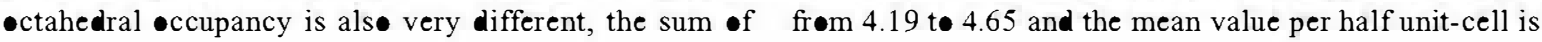

Table 2. Structural formulae from reference palygorskite (Attapulgus, Bercimuel and Torrejón) samples, calculated from EDS analyses of isolated palygorskite particles. The number of cations is on the basis of $\boldsymbol{\theta}_{20}\left(\mathbf{H}_{2}\right)_{2}\left(\mathrm{H}_{2}\right)_{2}$.

\begin{tabular}{|c|c|c|c|c|c|c|c|c|c|c|c|}
\hline & $\mathrm{Si}$ & ${ }^{\mathrm{rv}} \mathrm{Al}$ & $\Sigma \mathrm{t}$ & ${ }^{\mathrm{n}} \mathrm{Al}$ & $\mathrm{Fe}^{3+}$ & $\mathrm{Mg}$ & $\mathrm{Ti}$ & $\Sigma o$ & $\mathrm{Ca}$ & $\mathrm{K}$ & $\mathrm{Na}$ \\
\hline Att.1 & 7.74 & 0.26 & 8.00 & 1.55 & $\bullet .32$ & 2.07 & & 3.94 & 0.16 & 0.09 & 0.06 \\
\hline Att. 2 & 7.98 & 0.02 & 8.00 & 1.37 & 0.23 & 2.45 & 0.02 & 4.05 & 0.07 & 0.12 & 0.03 \\
\hline Att.3 & 7.84 & 0.16 & 8.00 & 1.50 & & 2.22 & & 3.72 & 0.09 & 0.05 & 0.19 \\
\hline Att. 4 & 7.92 & 0.08 & 8.00 & 1.40 & $\bullet .23$ & 2.45 & 0.01 & 4.08 & 0.06 & 0.02 & $\bullet .15$ \\
\hline Att. 5 & 7.83 & 0.17 & 8.00 & 1.52 & $\bullet .25$ & 2.34 & & 4.11 & 0.08 & 0.04 & \\
\hline Att. 6 & 7.82 & 0.18 & 8.00 & 1.42 & $\bullet .31$ & 2.29 & & 4.02 & 0.09 & 0.04 & 0.21 \\
\hline Att.7 & 7.85 & 0.15 & 8.00 & 1.44 & 0.25 & 2.47 & & 4.16 & 0.04 & 0.04 & \\
\hline Att. 8 & 7.81 & 0.16 & 7.97 & 1.48 & 0.28 & 2.35 & & 4.11 & 0.07 & 0.03 & \\
\hline Att. 10 & 7.90 & 0.10 & 8.00 & 1.59 & 0.35 & 2.06 & & 4.00 & 0.06 & 0.04 & \\
\hline Mean & 7.85 & 0.14 & 8.00 & 1.47 & 0.25 & 2.30 & 0.00 & 4.02 & 0.08 & 0.05 & 0.07 \\
\hline Ber.l & 7.88 & 0.12 & 8.00 & 1.78 & 0.36 & 1.74 & & 3.88 & 0.09 & 0.05 & \\
\hline Ber.2 & 7.79 & 0.21 & 8.00 & 1.66 & 0.38 & 1.96 & & 4.00 & 0.08 & 0.02 & \\
\hline Ber. 4 & 7.84 & 0.16 & 8.00 & 1.82 & $\bullet .37$ & 1.69 & & 3.88 & 0.05 & 0.09 & \\
\hline Ber .5 & 7.80 & 0.20 & 8.00 & 1.63 & 0.35 & 2.04 & & 4.02 & 0.06 & 0.06 & \\
\hline Ber.7 & 7.97 & 0.03 & 8.00 & 1.36 & 0.39 & 2.39 & & 4.14 & & & \\
\hline Ber. 6 & 8.09 & & 8.09 & 1.37 & 0.46 & 2.04 & & 3.87 & 0.03 & & \\
\hline Mean & 7.90 & •.12 & 8.02 & 1.60 & 0.39 & 1.98 & & 3.97 & 0.05 & 0.04 & \\
\hline Tor. 1 & 8.02 & & 8.02 & 1.50 & 0.30 & 2.26 & & 4.06 & & & \\
\hline Tor.2 & 7.81 & 0.19 & 8.00 & 1.53 & $\bullet .39$ & 2.12 & & 4.04 & 0.01 & 0.10 & \\
\hline Tor.3 & 7.85 & 0.15 & 8.00 & 1.47 & 0.37 & 2.29 & & 4.13 & 0.03 & 0.04 & \\
\hline Tor. 5 & 7.93 & 0.07 & 8.00 & 1.52 & 0.41 & 2.15 & & 4.08 & & & \\
\hline Tor. 5 & 7.97 & 0.03 & 8.00 & 1.44 & $\bullet .37$ & 2.31 & & 4.12 & & & \\
\hline Tor. 6 & 8.01 & & 8.01 & 1.40 & 0.3 & 2.29 & & 4.08 & & & \\
\hline Tor.8 & 7.82 & 0.18 & 8.00 & 1.52 & $\bullet .32$ & 2.31 & & 4.15 & 0.01 & 0.07 & \\
\hline Tor.1• & 7.88 & 0.12 & 8.00 & 1.39 & 0.44 & 2.32 & & 4.15 & & & \\
\hline Tor.11 & 7.91 & 0.09 & 8.00 & 1.51 & 0.37 & 2.23 & & 4.11 & & & \\
\hline Mean & 7.91 & 0.09 & 8.00 & 1.48 & 0.37 & 2.25 & & 4.10 & 0.01 & 0.02 & \\
\hline
\end{tabular}




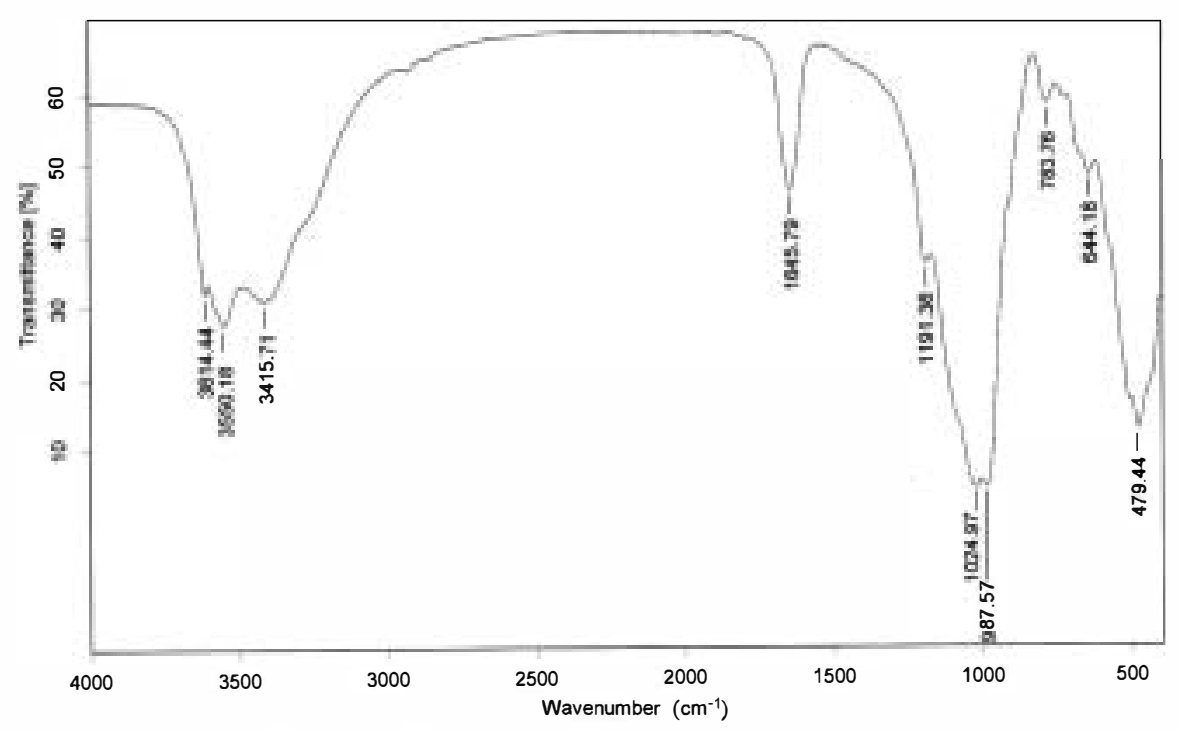

Figure 4. FTIR spectrum of the Esquivias palygorskite.

4.36 atoms. However, the sum of octahedral cations per half unit-cell ranges from 3.72 to 4.16 for the Attapulgus palygorskite, from 3.87 to 4.14 for Bercimuel palygorskite, and from 4.04 to 4.15 for Torrejón palygorskite; the mean values of number of octahedral cations are 4.02, 3.97 and 4.10 , respectively.

The FTIR spectrum of the Esquivias palygorskite is shown in Figure 4. The spectra for the Esquivias and reference samples are similar, but some important differences are found both in the intensity and in the position of the peak, especially in the region of minor wavenumbers. The positions of the bands corresponding to the four studied samples are listed in Table 3. In addition to the palygorskite bands, the three reference samples present bands corresponding to quartz (776-798 $\mathrm{cm}^{-1}$ ), and the Torrejón palygorskite presents those characteristic of calcite at 1433 and $876 \mathrm{~cm}^{-1}$ (Farmer, 1974).

\section{DISCUSSION}

The XRD patterns of pure palygorskite from Esquivias show the characteristic reflections of this mineral. The peaks are broader than those of the other palygorskites studied, probably due both to the small size of the particles and their poor crystallinity. With electron microscopy, the Esquivias palygorskite shows its characteristic fibrous morphology.

The Esquivias palygorskite is very rich in $\mathrm{Mg}$ according to the structural formula obtained by AEM. A comparative study of literature analyses (Table 4 shows 47 structural formulae for palygorskite), reference analyses (Table 2) and Esquivias analyses (Table 1) indicates that the Esquivias palygorskite has the largest number of $\mathrm{Mg}$ atoms of all the samples considered. The Esquivias palygorskite is also the sample with largest number of octahedral positions occupied, in part related to the high $\mathrm{Mg}$ content, which means that a higher occupancy is needed to complete the layer charge.

The octahedral cations of Esquivias palygorskite (Table 1) are mainly divalent (Mg from 2.73 to 3.86 atoms per half unit-cell) and minor trivalent cations (Al from 0.73 to 1.29 and $\mathrm{Fe}^{3+}$ from 0.10 to 0.32 atoms per half unit-cell). Table 5 illustrates a comparative study of palygorskite octahedral cations, and it shows the high $\mathrm{Mg}$ concentration of the Esquivias palygorskites.

Table 3. Positions (wavenumbers, $\mathrm{cm}^{-1}$ ) of bands and shoulders $\left(^{*}\right)$ found in FTIR spectra of the Esquivias and reference samples.

\begin{tabular}{lccc}
\hline Esquivias & Attapulgus & Bercimuel & Torrejón \\
\hline 3614 & 3615 & 3615 & 3614 \\
$3592^{*}$ & & $3588^{*}$ & $3577^{*}$ \\
3550 & 3547 & 3545 & 3548 \\
& & & $3473^{*}$ \\
3416 & 3422 & 3423 & 3415 \\
$3296^{*}$ & $3250^{*}$ & $3255^{*}$ & 3227 \\
1639 & 1652 & 1643 & 1639 \\
1617 & & & 1619 \\
& & & 1433 \\
1191 & 1194 & $1199^{*}$ & \\
& $1141^{*}$ & $<$ infl & $1198^{*}$ \\
1091 & 1091 & $<$ infl & $1127^{*}$ \\
1025 & 1032 & 1028 & $1095^{*}$ \\
987 & 987 & 993 & 1033 \\
& 913 & 918 & 987 \\
784 & & & 876 \\
729 & Q(776-798) & Q(776-798) & Q(776-798) \\
$683^{*}$ & & & \\
644 & 673 & 699 & 693 \\
$584^{*}$ & 648 & 647 & 645 \\
$515^{*}$ & 658 & $<$ infl & 583 \\
479 & 514 & 512 & 511 \\
\hline
\end{tabular}


Table 4. Sructural formulae for palygorskite taken from examples in the literature: $1-11$ compiled by Newman and Brown, (1978); 12 - 14 from Galán and Carretero (1999); 15-37 compiled by Galán and Carretero (1999); $38-43$ from Torres-Ruiz et al. (1994); 44 from López Galindo et al. (1966); 45 from Verrecchia and Le Coustumer (1996); 46 from Imai and Otsuka (1984); 47 from Hasnuddin Siddiqui (1984); and 48 from Chahi et al. (2002).

\begin{tabular}{|c|c|c|c|c|c|c|c|c|c|c|c|c|}
\hline & $\mathrm{Si}$ & ${ }^{\mathrm{rv}} \mathrm{Al}$ & $\Sigma \mathrm{t}$ & ${ }^{\mathrm{VI}} \mathrm{Al}$ & $\mathrm{Fe}^{3+}$ & $\mathrm{Mg}$ & $\mathrm{Ti}$ & $\mathrm{Fe}^{2+}$ & $\Sigma o$ & $\mathrm{Ca}$ & $\mathrm{K}$ & $\mathrm{Na}$ \\
\hline 1 & 7.34 & e. 66 & 8.00 & 2.25 & 0.17 & 1.47 & & & 3.89 & 0.21 & & \\
\hline 2 & 7.75 & 0.25 & 8.00 & 2.35 & 0.17 & 1.29 & & & 3.81 & $\bullet .06$ & & \\
\hline 3 & 7.61 & 0.39 & 8.00 & 2.26 & $\bullet .23$ & 1.43 & & & 3.92 & 0.02 & & \\
\hline 4 & 7.71 & 0.2 & 8.00 & 2.00 & 0.01 & 1.70 & & & 3.71 & & 0.08 & 0.08 \\
\hline 5 & 7.50 & 0.50 & 8.00 & 1.62 & $\bullet .41$ & 1.78 & & & 3.81 & $\bullet .34$ & & \\
\hline 6 & 8.06 & & 8.06 & 2.00 & 0.05 & 1.62 & & & 3.67 & 0.08 & 0.01 & 0.04 \\
\hline 7 & 7.80 & 0.20 & 8.00 & 1.51 & 0.38 & 2.22 & & & 4.11 & & 0.09 & \\
\hline 8 & 7.82 & 0.18 & 8.00 & 1.57 & 0.20 & 2.04 & & & 3.81 & $\bullet .36$ & & \\
\hline 9 & 8.09 & & 8.09 & 1.57 & 0.00 & 2.24 & & & 3.81 & 0.12 & 0.14 & 0.07 \\
\hline 10 & 7.88 & 0.12 & 8.00 & 0.95 & $\bullet .42$ & 2.81 & 0.10 & & 4.28 & & & \\
\hline 11 & 7.75 & 0.25 & 8.00 & 0.12 & $0.1 \bullet$ & 3.84 & 0.08 & & 4.14 & 0.17 & 0.04 & 0.21 \\
\hline 12 & 7.71 & 0.29 & 8.00 & 1.43 & $\bullet .56$ & 2.10 & & & 4.09 & & & \\
\hline 13 & 7.86 & 0.14 & 8.00 & 1.84 & 0.40 & 1.71 & & & 3.95 & & & \\
\hline 14 & 8.05 & & 8.05 & 1.46 & 0.41 & 2.09 & & & 3.96 & & & \\
\hline 15 & 7.81 & 0.19 & 8.00 & 1.40 & 0.48 & 1.99 & & & 3.87 & 0.04 & 0.06 & 0.32 \\
\hline 16 & 7.80 & 0.20 & 8.00 & 1.13 & 0.87 & 1.83 & & & 3.83 & 0.14 & $\bullet .23$ & 0.03 \\
\hline 17 & 7.66 & 0.34 & 8.00 & 1.52 & 0.15 & 2.65 & & & 4.32 & 0.04 & 0.04 & \\
\hline 18 & 8.05 & & 8.05 & 1.68 & 0.10 & 2.20 & & & 3.98 & 0.02 & & \\
\hline 19 & 7.85 & $\bullet .15$ & 8.00 & 1.15 & 0.38 & 2.53 & 0.08 & & 4.14 & & & \\
\hline 20 & 7.98 & 0.21 & 8.19 & 1.29 & $\bullet .37$ & 1.96 & & 0.03 & 3.62 & $\bullet .32$ & & \\
\hline 21 & 7.89 & 0.11 & 8.00 & 1.87 & 0.16 & 1.91 & & & 3.94 & 0.05 & & 0.03 \\
\hline 22 & 7.64 & $\bullet .36$ & 8.00 & 1.73 & $\bullet .63$ & 1.45 & & & 3.81 & 0.08 & & \\
\hline 23 & 7.79 & 0.21 & 8.00 & 1.52 & 0.31 & 1.89 & 0.05 & & 3.77 & $\bullet .31$ & 0.05 & 0.08 \\
\hline 24 & 7.43 & 0.57 & 8.00 & 1.58 & 0.65 & 1.66 & & & 3.89 & 0.06 & 0.21 & 0.14 \\
\hline 25 & 7.35 & e. 65 & 8.00 & 1.29 & 0.47 & 2.20 & & & 3.96 & $\bullet .20$ & 0.12 & 0.45 \\
\hline 26 & 7.66 & 0.34 & 8.00 & 1.48 & $\bullet .46$ & 2.02 & 0.03 & & 3.99 & 0.05 & 0.15 & 0.13 \\
\hline 27 & 7.58 & 0.42 & 8.00 & 0.87 & 0.81 & 2.42 & 0.08 & & 4.18 & 0.08 & 0.08 & 0.03 \\
\hline 28 & 7.50 & 0.50 & 8.00 & 1.68 & 0.54 & 1.77 & & & 3.99 & & 0.27 & \\
\hline 29 & 7.79 & 0.21 & 8.00 & 1.06 & $\bullet .56$ & 2.46 & 0.02 & & 4.10 & 0.06 & 0.06 & 0.03 \\
\hline 30 & $7.7 \bullet$ & 0.30 & 8.00 & 1.27 & $\bullet .63$ & 2.06 & 0.06 & & 4.02 & $\bullet .06$ & 0.06 & 0.05 \\
\hline 31 & 7.86 & 0.14 & 8.00 & 2.11 & 0.22 & 1.12 & & & 3.45 & $\bullet .43$ & & \\
\hline 32 & 7.64 & 0.36 & 8.00 & 2.27 & 0.23 & 1.40 & & & 3.90 & 0.02 & & \\
\hline 33 & 7.61 & 0.39 & 8.00 & 1.81 & & 2.52 & & & 4.33 & 0.04 & & \\
\hline 34 & 7.33 & 0.67 & 8.00 & 2.37 & & 1.69 & & & 4.06 & 0.08 & & \\
\hline 35 & 7.99 & 0.01 & 8.00 & 1.62 & 0.05 & 1.90 & 0.05 & 0.45 & 3.62 & & 0.08 & \\
\hline 36 & 8.04 & & 8.04 & 1.05 & 0.08 & 2.75 & & & 3.88 & 0.08 & & \\
\hline 37 & 7.52 & 0.48 & 8.00 & 2.08 & 0.17 & 1.37 & 0.04 & & 3.66 & 0.15 & •.30 & 0.16 \\
\hline 38 & 8.00 & & 8.00 & 1.22 & $\bullet .66$ & 1.75 & 0.09 & & 3.72 & & 0.05 & 0.05 \\
\hline 39 & 8.00 & & 8.00 & 1.13 & $\bullet .63$ & 1.98 & 0.08 & & 3.82 & 0.03 & 0.06 & 0.05 \\
\hline 40 & 7.20 & 0.80 & 8.00 & 1.36 & 1.31 & 1.07 & $\bullet .11$ & & 3.85 & & 0.07 & 0.15 \\
\hline 41 & 7.37 & 0.63 & 8.00 & 1.12 & 1.16 & 1.43 & 0.09 & & 3.80 & 0.19 & 0.06 & •. 13 \\
\hline 42 & 8.00 & & 8.00 & 1.29 & 0.38 & 2.24 & 0.06 & & 3.97 & 0.00 & 0.05 & 0.02 \\
\hline 43 & 8.00 & & 8.00 & 1.16 & 0.37 & 2.43 & 0.06 & & 4.02 & 0.08 & 0.05 & 0.03 \\
\hline 44 & 7.79 & 0.21 & 8.00 & 1.64 & 0.42 & 1.90 & & & 3.96 & $\bullet .03$ & 0.12 & \\
\hline 45 & 8.01 & & 8.01 & 1.61 & $\bullet .53$ & 2.35 & & & 4.49 & 0.11 & 0.28 & \\
\hline 46 & 7.83 & 0.17 & 8.00 & 1.58 & 0.19 & 2.04 & & 0.03 & 3.84 & $\bullet .36$ & & \\
\hline 47 & 7.80 & 0.20 & 8.00 & 1.13 & 0.87 & 1.83 & & & 3.83 & 0.14 & $\bullet .23$ & 0.03 \\
\hline 48 & 8.00 & & 8.00 & 1.19 & - .33 & 2.60 & & & 4.12 & 0.06 & 0.10 & 0.02 \\
\hline Mean & 7.76 & 0.25 & 8.01 & 1.52 & •.39 & 1.99 & 0.02 & 0.01 & 3.94 & 0.10 & 0.07 & 0.05 \\
\hline
\end{tabular}

Althøugh Bradley (1940) propesed the pøssibility of triectahedral palygerskite, at present the accepted model has palygorskite intermediate between $\mathrm{di}$ and triectahedral phyllesilicate (Bailey, 1980; Drits and Aleksandrøva, 1966; Paquet et al., 1987), with 21 exygens for a half, dehydrated, unit-cell, with formula: $\left(\mathrm{Si}_{8}{ }_{x} \boldsymbol{R}_{x}^{3+}\right)\left(\mathrm{Mg}_{5}\right.$ y $\left._{z} \boldsymbol{R}_{y}^{3+} \square_{z}\right) \boldsymbol{\bullet}_{20}$

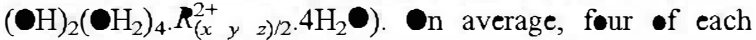

five ectahedral positions are eccupied. According to Newman and Brøwn (1987), the sum of $\bullet$ chedral cations lies between 3.76 and 4.64 , with a mean value of 4.00 , indicating that palygerskite should be classed as a diecthedral mineral. $\mathrm{Al}, \mathrm{Fe}^{3+}$ and $\mathrm{Fe}^{2+}$ are the main elements which substitute for $\mathrm{Mg}$. The Esquivias palygorskite has the largest sum of ectahedral cations (4.36) 
Table 5. Octahedral occupancy ranges (maximum, minimum and means values), from the literature, patterns and Esquivias samples. ${ }^{\mathrm{VI}}\left(R^{2}+R^{3}\right)=$ octahedral cations other than $\mathrm{Mg}$; they are mainly $\mathrm{Al}$ and $\mathrm{Fe}^{3+}$.

\begin{tabular}{lcccccc}
\hline & Octahedral cations & ${ }^{\mathrm{V}} \mathrm{Mg}$ & ${ }^{\mathrm{VI}}(R 2+R 3)$ & $\mathrm{Mg} / \mathrm{Al}$ & $\mathrm{Si} / \mathrm{Mg}$ & $\mathrm{Mg} /\left(\mathrm{Al}^{+}+\mathrm{Fe}^{3+}\right)$ \\
\hline Literature & $3.62-4.49(3.94)$ & $0.93-3.08(1.99)$ & $1.12-2.67(1.91)$ & 1.37 & 4.04 & 1.06 \\
Attapulgus & $3.72-4.16(4.02)$ & $2.06-2.47(2.30)$ & $1.50-1.94(1.72)$ & 1.44 & 3.43 & 1.35 \\
Torrejón & $4.04-1.15(4.10)$ & $2.12-2.32(2.25)$ & $1.79-1.93(1.85)$ & 1.19 & 4.04 & 1.01 \\
Bercimuel & $3.87-4.14(3.97)$ & $1.69-2.39(1.98)$ & $1.75-2.19(1.99)$ & 1.44 & 3.51 & 1.22 \\
Esquivias & $4.18-4.65(4.36)$ & $2.73-3.86(3.11)$ & $0.79-1.55(1.24)$ & 2.72 & 2.54 & 2.58 \\
\hline
\end{tabular}

compared with reference samples and literature analyses (with the exception of sample 45 (Table 4) from Verrecchia and Le Coustumer (1996)), the Mg constitutes between 29 and $79 \%$ of the octahedral cations and $\mathrm{Al}$ between 28 and $59 \%$. Newman and Brown (1987) affirm

cations range from $\sim 2 \frac{1}{2}$ trivalent plus $1 \frac{1}{2}$ divalent from samples abundant in $\mathrm{Al}$, to $1 \frac{1}{2}$ trivalent with $2 \frac{1}{2}$ divalent for the palygorskite from Queensland (sample 10, Table 4), and even to $1 / 2$ trivalent with $4 \frac{1}{2}$ divalent for a highly magnesic sample (sample 11, Table 4, from the Volhynia basalts, USSR, Drits and Aleksandrova, 1966). By comparison with these authors and with the literature analyses, the Esquivias palygorskite has the highest proportion of $\mathrm{Mg}$, comparable only to the highly magnesic sample from Drits and Aleksandrova (1966). Likewise, Esquivias palygorskite shows a $\mathrm{Mg} / \mathrm{Al}$ and $\mathrm{Mg} / \mathrm{Si}$ ratio double that of reference and bibliography samples.

The ratio between divalent and trivalent octahedral cations $R 2 / R 3\left(\mathrm{Mg} / \mathrm{Al}+\mathrm{Fe}^{3+}\right)$ in palygorskite analyses from Attapulgus, Bercimuel and Torrejón has average values close to 1 (1.35, 1.01 and 1.22 respectively). Galán and Carretero (1999) affirmed that palygorskite contains mainly $\mathrm{Mg}, \mathrm{Al}$ and $\mathrm{Fe}$ with an $R 2 / R 3$ ratio close to 1 , similar to the value found in our reference samples. The Esquivias samples show an $R 2 / R 3$ of 2.58 (Table 5 ).

Moreover, this mineral can contain variable amounts of other cations, such as $\mathrm{Na}, \mathrm{Ca}$ and $\mathrm{K}$ as exchange cations. Some authors, such as Velde (1985) and Galán and Carretero (1999), suggest that the presence of cations such as $\mathrm{Ca}, \mathrm{K}$ and $\mathrm{Na}$ in the analyses of palygorskite is probably due to impurities (calcite, illite) and they are not exchange cations. However, palygorskite is compose of very small fibers and for this reason, the particle edges have a strong influence on its ionic exchange capacity. Besides, the coordination of octahedral cations at each edge of the octahedral sheet is completed with two water molecules and therefore allows new cations to be bonded to these water molecules in the particle edges. Thus, palygorskite has exchange capacities in the region of $57-300 \mu \mathrm{eg}^{-1}$ (Newman and Brown, 1987).

The chemical data are plotted on different diagrams as shown in Figure $5(\mathrm{Si} / \mathrm{Mg}$ vs. R3/R2) and Figure 6 $\left(\left(\mathrm{Al}+\mathrm{Fe}^{3+}\right)^{\mathrm{VI}}\right.$ vs. $\left.\mathrm{Mg}\right)$. In both cases, the reference and bibliography samples are distributed through a similar domain, but in contrast, the Esquivias samples plot in a separate domain. On Figure 5 we also plotted sepiolite chemical data from Newman and Brown (1978). It is noticeable here that the Esquivias data plot between the palygorskite and sepiolite samples.

The aim of the FTIR spectroscopic study is to gain knowledge of the environment of the octahedral cations. The FTIR spectra of Esquivias palygorskites and the other samples studied are similar both in the position of the bands and in intensity. There are three bands at 3615 , 3548 and $3420 \mathrm{~cm}^{-1}$ and two shoulders at 3580 and

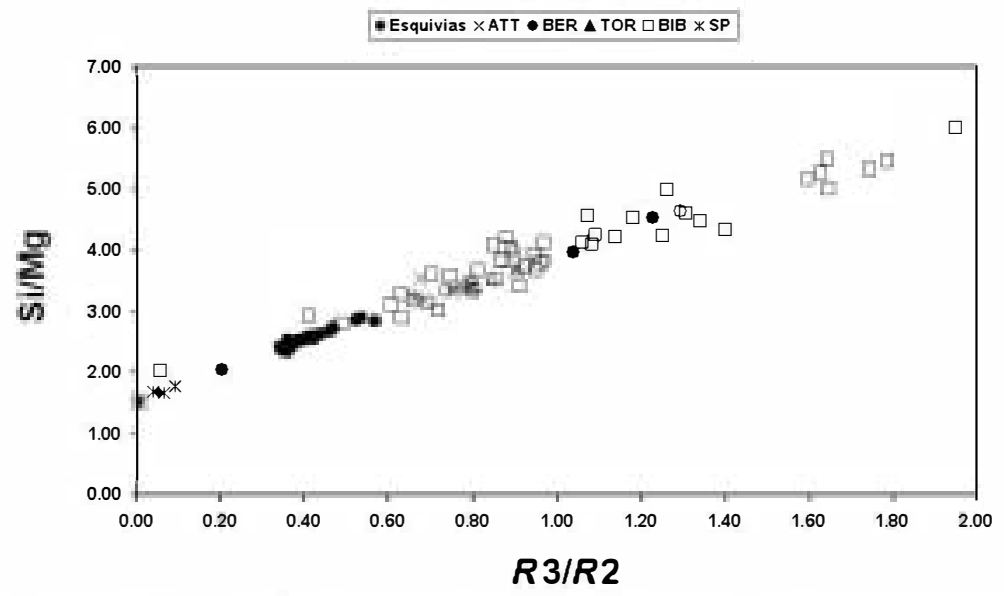

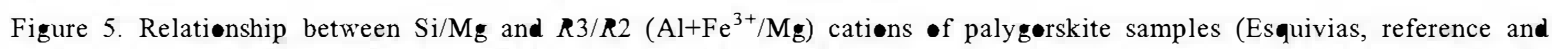
bibliøgraphy) and sepiølite chemical data frøm Newman and Brøn (1978). ATT = Attapulgus, BER $=B e r c i m u e l, T O R=T \bullet r r e j \bullet n$

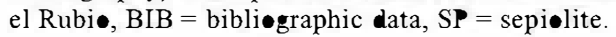




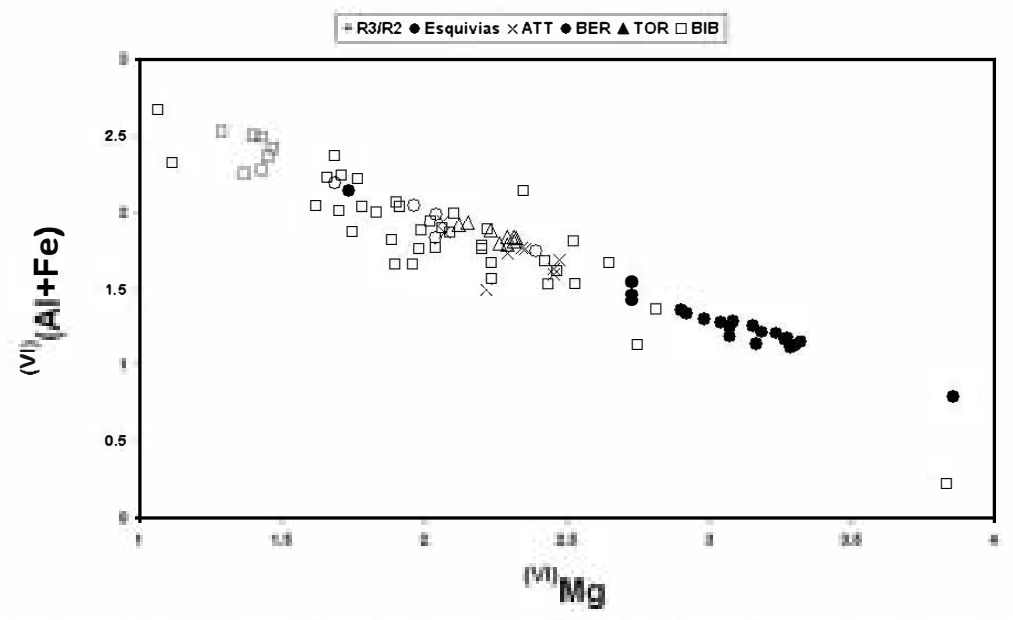

Figure 6. Relationship between $(\mathrm{Al}+\mathrm{Fe})$ and $\mathrm{Mg} \bullet \mathrm{f}$ the Esquivias palygorskite and reference samples. Abbreviatiøns as in Figure 5 .

$325 \mathrm{~cm}^{-1}$. The bands are due to the presence of different types of water molecules in the structure of the clay (coordinated and zeolitic water), and to the presence of $\mathrm{OH}$ groups coordinated to metallic cations. These bands and shoulders are reported in the literature for these and other palygorskites. The coincidence in the position of the band at $3615 \mathrm{~cm}^{-1}$ which always appears in palygorskite (both in the studied samples and in those from the literature) but not in sepiolite studies is especially significant. This band is assigned to the stretching mode of the structural hydroxyls bonded to the different cations ( $M_{3}-\mathrm{OH}$ stretching) mainly $\mathrm{Al}$, in an octahedral coordination (Mendelovichi, 1973; Serna et al., 1977; Khorami and Lemieux, 1989; Vicente González et al., 1996; Ausburger et al., 1998; and Frost et al., 2001).

For a theoretical palygorskite with structural formula $\mathrm{Si}_{8}\left(\mathrm{Mg}_{2} \mathrm{Al}_{2}\right) \mathrm{O}_{2} \cdot(\mathrm{OH})_{2}\left(\mathrm{OH}_{2}\right)_{4} \cdot 4 \mathrm{H}_{2} \mathrm{O}$, Güven (1992) proposed the configuration of the octahedral ribbons plotted in Figure $7 \mathrm{a}$, with $M 1, M 2$ and $M 3$ sites, where $M 3$ is occupied by $\mathrm{Mg}, M 2$ is occupied by $\mathrm{Al}$ or $\mathrm{Fe}$ and $M 1$ sites are vacant, and the band at $3615 \mathrm{~cm}^{-1}$ is due to $\mathrm{Al}_{2} \square-\mathrm{OH}$ or $\mathrm{AlFe} \square-\mathrm{OH}$. Also, values of $3620-3614 \mathrm{~cm}^{-1}$ are reported for other dioctahedral configurations such as AlMg $\square-\mathrm{OH}$, and $\mathrm{Mg}_{2} \square-\mathrm{OH}$, the latter in sepiolite (Hayasi et al., 1969; Prost, 1973; Frost et al., 2001). The Esquivias palygorskite does not show a band at $368 \mathrm{~cm}^{-1}$; this is known to be due to $\mathrm{OH}$ stretching in $\mathrm{Mg}_{3}-\mathrm{OH}$ in a trioctahedral structure (Frost et al., 2001 and previous works) although this sample has a very high $\mathrm{Mg}$ content and the octahedral occupancy is close to trioctahedral.

The distribution of $\mathrm{Mg}, \mathrm{Al}$ and $\mathrm{Fe}$ ions and of the vacancies in the ribbon of the palygorskite is plotted in Figure 7 using the scheme of Güven (1992) and taking into account the mean values obtained for the structural formulae of the Esquivias palygorskite. Two possibilities are taken into account: (1) the vacancies, the $\mathrm{Al}$ and the small $\mathrm{Fe}$ content are distributed homogeneously in the
M2 positions (Figure 7b); (2) the distribution is made assuming the existence of trioctahedral clusters, i.e. the existence of $\mathrm{Mg}$ in $M 2$ positions (Figure 7c). With this latter possibility, $\sim 33 \%$ of the ribbon is trioctahedral, and as a consequence of this, a small band at $368 \mathrm{~cm}^{-1}$ should be observed in the IR spectra, but this band is not found. In the model proposed in Figure $7 \mathrm{~b}$ the high $\mathrm{Mg}$ content can be distributed without trioctahedral domains. The Mg occupies $M 3, M 2$ and also $M 1$ positions but there is no $\mathrm{Mg}_{3}-\mathrm{OH}$ configuration. However, this model presents a small part of the ribbon with an excess of octahedral charge which can be compensated by the location of the tetrahedral substitution ( $\mathrm{Si}$ for $\mathrm{Al}$ ) in the same region. Thus, the distribution of the large number of octahedral cations in the structure of the Esquivias palygorskite is only possible with a highly ordered arrangement in the octahedral sheet.

In the minor wavenumbers' region of the IR spectra there are important differences between the Esquivias palygorskite and other samples. The bands corresponding to impurities are also found. Two bands centered at 798 and $776 \mathrm{~cm}^{-1}$, characteristic of quartz, are present in the three reference samples and, in the Torrejón palygorskite, two bands at 1453 and $88 \mathrm{~cm}^{-1}$ corresponding to calcite are also found. Between 1200 and $400 \mathrm{~cm}^{-1}$, bands characteristic of silicate can be observed, mainly those corresponding to $\mathrm{Si}-\mathrm{O}$ bonds in the tetrahedral sheet, and also to $M-O$-stretching vibrational bonds. This region of the spectra is very complex because the lattice modes also contribute, but it is especially interesting because it provides information about the nature of the octahedral sheet. In a recent study that takes into account the lattice dynamic calculations for the palygorskite structure (McKeown et al., 2002), it is considered that "above $700 \mathrm{~cm}^{-1}$ in the IR spectra, the eigenmodes are dominate by atomic displacements within the silicate sheets. Below $700 \mathrm{~cm}^{-1}$ the eigenmodes become mixed with motions among the $\mathrm{Mg}$ octahedra and the silicate sheets. As mode frequencies 

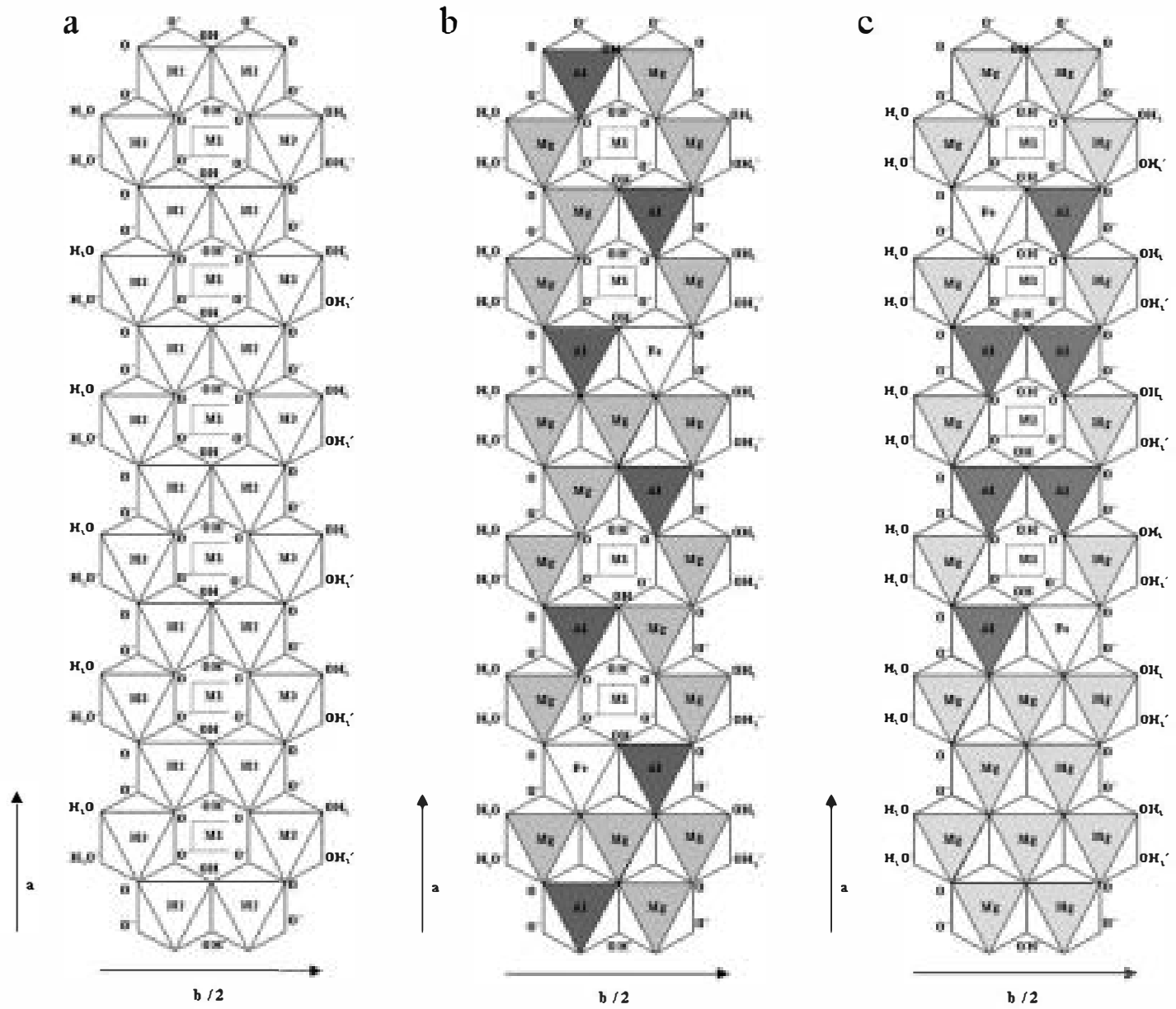

Figure 7. (a) Configuration of the octahedral ribbons in the palygorskite structure having $M 1, M 2$ and $M 3$ octahedral sites after Güven (1992). $\mathrm{O}^{\prime}, \mathrm{O}^{\prime \prime}, \mathrm{OH}^{\prime}$ and $\mathrm{H}_{2} \mathrm{O}^{\prime}$ belong to the top triangles of the octahedra in this projection. (b) Possible distribution of the octahedral cations in the Esquivias palygorskite with the Mg distributed homogeneously along the fiber. (c) Possible distribution of the octahedral cations in the Esquivias palygorskite with the $\mathrm{Mg}$ distributed in clusters.

decrease, the corresponding eigenmodes evolve from more localized $\mathrm{Mg}-\mathrm{O}$ stretch, $\mathrm{O}-\mathrm{Mg}-\mathrm{O}$ bend and $\mathrm{O}-\mathrm{Si}-\mathrm{O}$ bend motions to longer-range motions such as silicate sheet deformations caused by silicate tetrahedra rotation and silicate sheet shearing around the Mgoctahedral sheets". In this region, in the sequence of $\mathrm{Si}-\mathrm{O}-\mathrm{M}-\mathrm{O}-\mathrm{Si}$ bonds, a very important factor is the nature of $M(\mathrm{Mg}, \mathrm{Al}, \mathrm{Fe} \ldots)$ while the trioctahedral or dioctahedral surrounding has less influence. In the reference samples the $\mathrm{Mg}, \mathrm{Al}$ and $\mathrm{Fe}$ contents are similar and their influence produces different bands due to the possible $M-M-\mathrm{OH}$ and $M-M-\mathrm{O}$ bonds. Chahi et al. (2002) attribute the bands at 911,867 and $834 \mathrm{~cm}^{-1}$ to $\mathrm{Al}-\mathrm{Al}-\mathrm{OH}, \mathrm{Al}-\mathrm{Fe}-\mathrm{OH}$ and $\mathrm{Al}-\mathrm{Mg}-\mathrm{OH}$, respectively. In the Esquivias palygorskite, a simpler aspect is observed in this region of the spectra due to preponderance of $\mathrm{Mg}$ in the octahedral sheet, the more intense bands are due to high $\mathrm{Mg}$ content: $\mathrm{Mg}-\mathrm{Mg}-\mathrm{O}$ at $648 \mathrm{~cm}^{-1}$ and $\mathrm{Mg}-\mathrm{Mg}-\mathrm{OH}$ or $\mathrm{Mg}-(\mathrm{Al}, \mathrm{Fe})-\mathrm{OH}$ at $784 \mathrm{~cm}^{-1}$ (Augsburger et al., 2001).
Only one other possibility can be suggested: a possible random intergrowth between palygorskite and sepiolite such as that reported by Martín Vivaldi and Linares González (1962) in the bentonites of Cabo de Gata (Almería, Spain), but this sepiolite should have a large number of octahedral vacancies.

\section{CONCLUSIONS}

The Esquivias palygorskite has the highest $\mathrm{Mg}$ content reported in the literature to date. Chemically, this palygorskite could fill the compositional gap existing between sepiolite and palygorskite. The FTIR studies show that this is possible without the existence of $\mathrm{Mg}_{3}-\mathrm{OH}$ bonds. No $\mathrm{Mg}$ pure clusters are found, though octahedral occupancy is very high $(90 \%)$, with a percentage similar to the other trioctahedral clay minerals. The distribution of the large number of octahedral cations in the structure of the Esquivias palygorskite is only possible with a highly ordered 
arrangement in the ectahedral sheet and an homegeneous distribution of different $\bullet$ ctahedral cations and vacancies aleng the ectahedral sheet is propesed.

\section{ACKNOWLEDGENTS}

The authors thank Dr Angela Arteaga for technical assistance and are also very grateful to Dr Arieh Singer and Dr Blair Jones for their constructive comments. Financial support by CICYT (project BTE2002-04017$\mathrm{CO} 2)$ is acknowled ged.

\section{REFERENCES}

Augsburger, M.S., Strasser, E., Perino, E., Mercader, R.C. and Pedregosa, J.C. (1998) FTIR and Mössbauer investigation of a substituted palygorskite: silicate with a channel structure. Journal of Physical Chemical S•lids, 59, 175-180.

Bellanca, A., Calvo, J.P., Censi, P., Neri, R. and Pozo, M. (1992) Recognition of lake-level changes in Miocene lacustrine units, Madrid basin, Spain. Evidence from facies analysis, isotope geochemistry and clay mineralogy. Sedimentary Geology, 76, 135-153.

Bailey, S.W. (1980) Structure of layer silicates. Pp.1-123 in: Crystal Structures of Clay Minerals and their X-ray Identification (G.W. Brindley and G. Brown, editors). Monograph 5, Mineralogical Society, London.

Bradley, W.F. (1940) The structural scheme of attapulgite. American Mineralogist, $25,405-411$.

Bustillo, M.A. and García Romero, E. (2003) Arcillas fibrosas anómalas en encostramientos y sedimentos superifciales: características y génesis (Esquivias, Cuenca de Madrid). Boletín Sociedad Española de Cerámica y Vidrio, 42 , 289-297.

Chahi, A., Petit, S. and Decarreau, A. (2002) Infrared evidence of dioctahedral-trioctahedral site occupancy in palygorskite. Claz and Clin Minerals 50, 306-313.

Drits, V.A. and Alexandrova, V.A. (1966) On the crystallographic nature of palygorskites. Zapiski Vsesøuzn $\bullet$ Mineral•gichesk•g• bshchestva, 95, 551-560.

Drits, V.A. and Sokolova, G.V. (1971) Stucture of palygorskite. Søviet Physics Crystallography, 16, 288-231.

Farmer, V.C. (1974) The Infrared Spectra of Minerals. Monograph 4, Mineralogical Society, London.

Frost, R.L., Locos, O.B., Ruan, J. and Kloprogge, J.T. (2001) Near-infrared and mid-infrared spectroscopic study of sepiolites and palygorskites. Vibrational Spectroscopy, 27 $1-3$.

Galán, E. and Carretero, I. (1999) A new approach to compositional limits for sepiolite and palygorskite. Clays and Cloy Minenaiz, 47,399-409.

Galán, E. and Castillo, A. (1984) Sepiolite-palygorskite in Spanish tertiary basins: Genetic patterns in continental environments. Pp. 87-124 in: Palyg•rskite-Sepi॰lite. -ccurrences, Genesis and Uses. (A. Singer and E. Galán, editors). Developments in Sedimentology, 37. Elsevier, Amsterdam.

Galán, E. and Ferrero, A. (1982) Palygorskite-sepiolite clays of Lebrija, Southern Spain. Clays and Clay Minerals, 30, 191-199.

García Romero, E. (1988) Estudio mineralógico y estratigráfico de las arcillas de las facies centrales del Neógeno del borde sur de la Cuenca del Tajo. PhD thesis, Universidad Complutense, Madrid, Spain, 436 pp.

González, M. and Galán, E. (1984) Mineralogía de los materiales terciarios del área de Tarazona Borja-Ablitas (Depresión del Ebro). Estudiøs Ge•lógic•s, 40, 115-128.

Güven, N. (1992) The coordination of aluminum ions in the palygorskite structure. Clays and Clay Millerals. 40. 457-461.

Hasnuddin Siddiqui, M.K. (1984) Occurrence of palygorskite in the Deccan Trap Formation in India. Pp. 243-250 in: Palyg•rskite-Sepiølite. Ccurrences, Genesis and Uses (A. Singer and E. Galán, editors). Developments in Sedimentology, 37. Elesevier, Amsterdam.

Hayasi, H., Otsuka, R. and Imai, N. (1969) Infrared study of sepiolite and palygorskite on heating. American Mineraløist, 53, 1613-1624.

Imai, N. and Otsuka, R. (1984) Sepiolite and palygorskite in Japan. Pp. 211-232 in: Palyg•rskite-Sepi•lite. -ccurrences, Genesis and Uses. (A. Singer and E. Galán editors). Developments in Sedimentology, 37. Elsevier. Amsterdam.

Jones, B.F. and Galán, E. (1991) Sepiolite and palygorskite. Pp. 631-674 in: Hydrøus Phylløsilicates (exclusive of mics) (S.W. Bailey, editor). Reviews in Mineralogy, 19. Mineralogical Society of America, Washington, D.C.

Khorami, J. and Lemieux, A. (1989) Comparison of attapulgites from different sources using TG/DTG and FTIR. Thermochimica Acta, 138.97-105.

Leguey, S., Pozo, M. and Medina, J.A. (1985) Polygenesis of sepiolite and palygorskite in a fluvio-lacus rine environment in the Neogene Basin of Madrid. Mineralogica Petrographic Acta, 29A, 807-301.

López Galindo, A., Ben Aboud, P., Fenoll Hach-Ali, P. and Casas Ruiz, J. (1996) Mineralogical and geochemical characterization of palygorskite from Gabasa (NE Spain. Evidence of a detrital precursor. Clay Minerals, 31, 33-44.

Martín Vivaldi, J.L. and Linares Gonzalez, J. (1962) A random intergrowth of sepiolite and attapulgite. Clays and Clay Minerals, 9, 592-602.

McKeown, D.A., Post, J.E. and Etz, E.S. (2002) Vibrational analysis of palygorskite and sepiolite. Clays and Clay Minerals. 50, $667 \quad 680$.

Mendelovici, E. (1973) Infrared study of attapulgite and $\mathrm{HCl}$ weated attapulgite. Clows and Clay Minerals, 21, 115-119.

Mifsud, A., Rautureau, M. and Fornes, V. (1978) Etude de l'eau dans la palygorskite a l'aide des analyses thermiques. Clay Minerals, $13,367-374$.

Newman, A.C.D. and Brown, G. (1987) Palygorskite and sepiolite. Pp. 107-112 in: Chemistry of Clays and Clay Minerals (A.C.D. Newman, editor). Monograph 6, Mineralogical Society, London.

Paquet, H., Duplay, J., Valleron-Blanc, M.M. and Millot, J. (1987) Octahedral compositions of individual particles in smectite-palygorskite and smectite-sepiolite assemblages. Proceedings of the International Clay Conference, Denver, pp. 73-77.

Pozo, M., Medina, J.A. and Leguey, S. (1985) Mineralogénesis de paligorskita en la zona central de la Cuenca de Madrid.

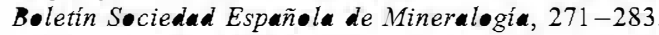

Prost, R. (1973) Spectre infrarouge de l'eau presente dans l'attapulgite et la sepiolite. Bulletin Française Argiles, XXV, 53-63.

Serna, C., Van Scoyoc, G.E. and Ahlrichs, J.L. (1977) Hydroxyl groups and water in palygorskite. American Mineralogist, 62, 784-792.

Singer, A. and Norrish, K. (1974) Pedogenic palygorskite occurrences in Australia. American Mineralogist. 59 $\underline{508-517}$

Suárez, M., Robert, M., Elsass, F. and Martín-Pozas, J.M. (1994) Evidence of a precursor in the neoformation of palygorskite - New data by analytical electron microscopy. Clar Aftuerals, 29, 255-264.

Suárez, M., Flores, L.V. and Martín Pozas, J.M. (1995) Mineralogical data for palygorskite from Bercimuel (Segovia. Spain). Clay Minerals, 30, 261-266. 
Torres-Ruiz, J., López Galindo, A., González-López, J.M. and Delgado, A. (1994) Geochemistry of Spanish sepiolitepalygorskite deposits: Genetic considerations based on race elements and isotopes. Chemical Geology, 112,221-245.

Velde, B. (1985) Clay Minerals. A Physic-Chemical Explanation of their ccurrence. Developments in Sedimentology, 40. Elsevier, Amsterdam.

Verrecchia, E.P. and Le Coustumer, M.N. (1996) Occurrence and genesis of palygorskite and associated clay minerals in a Pleistocene calcrete complex, Sde Boqer, Negev Desert, Israel. Clay Minerals, 31, 183-202.
Vicente González, M.A., Suárez, M., Bañares, M.A. and López González, J. de D. (1996) Comparative FT-IR study of the removal of octahedral cations and structural modifications during acid treatment of several silicates. Spectremic $\operatorname{Acta}(A), 52,1685-1694$.

Weaver, C.E. and Beck, K.C. (1977) Miocene of the S.E. United States; A Model for chemical sedimentation in a peri-marine environment. Sedimentary Ge•l•gy, 17, 234 pp. 